\title{
Personality Traits That Affect Travel Intentions during Pandemic COVID-19: The Case Study of Serbia
}

\author{
Jelena Tepavčević ${ }^{1}\left(\mathbb{D}\right.$, Ivana Blešić $\left.{ }^{1,2}{ }^{(}\right)$, Marko D. Petrović $\left.{ }^{2,3}{ }^{(}\right)$, Svetlana Vukosav ${ }^{1, *}$, Milan Bradić ${ }^{1}$, \\ Vuk Garača ${ }^{1}$, Tamara Gajić ${ }^{2,3}$ (1) and Dobrila Lukić ${ }^{4}$
}

1 Department of Geography, Tourism and Hotel Management, Faculty of Science, University of Novi Sad, Trg Dositeja Obradovića 3, 21000 Novi Sad, Serbia; jelenat@dgt.uns.ac.rs (J.T.); ivana.blesic@dgt.uns.ac.rs (I.B.); milan.bradic@dgt.uns.ac.rs (M.B.); vuk.garaca@dgt.uns.ac.rs (V.G.)

2 Institute of Sports, Tourism and Service, South Ural State University, 76 Lenin Ave., 454080 Chelyabinsk, Russia; m.petrovic@gi.sanu.ac.rs (M.D.P.); tamara.gajic.1977@gmail.com (T.G.)

3 Geographical Institute "Jovan Cvijić", Serbian Academy of Sciences and Arts, Đure Jakšića 3, 11000 Belgrade, Serbia

4 Eighth Belgrade Grammar School, Grčića Milenka 71, 11000 Belgrade, Serbia; dobriladjerdap@gmail.com

* Correspondence: svetlana.vukosav@dgt.uns.ac.rs

check for updates

Citation: Tepavčević, J.; Blešić, I.; Petrović, M.D.; Vukosav, S.; Bradić, M.; Garača, V.; Gajić, T.; Lukić, D. Personality Traits That Affect Travel Intentions during Pandemic COVID-19: The Case Study of Serbia. Sustainability 2021, 13, 12845. https:/ / doi.org/10.3390/su132212845

Academic Editors: Kisang Ryu and Nikolaos Boukas

Received: 30 September 2021 Accepted: 15 November 2021 Published: 19 November 2021

Publisher's Note: MDPI stays neutral with regard to jurisdictional claims in published maps and institutional affiliations.

Copyright: (c) 2021 by the authors. Licensee MDPI, Basel, Switzerland. This article is an open access article distributed under the terms and conditions of the Creative Commons Attribution (CC BY) license (https:// creativecommons.org/licenses/by/ $4.0 /)$.

\begin{abstract}
The pandemic caused by COVID-19 has enormous effects on peoples' lives and on the global economy. The outbreak and effects of COVID-19 have resulted in fears, concerns, and anxiety among people all around the world. The aim of this study is to investigate the relationship between the fear of COVID-19, travel anxiety, and travel intention among residents in Serbia. In addition to the above, the aim of the study was to examine the impact of personality traits on the fear of COVID-19, travel anxiety, and travel intentions. To enhance the understanding of the relationship between the mentioned variables, this study proposes a research model based on the use of measurement scales from the existing studies to develop the questionnaire. The standard paper-and-pen survey was used for data collection from the respondents from Serbia. The total sample include 987 respondents. It was determined that Travel intention was negatively influenced by Neuroticism and Conscientiousness, but positively by Extroversion and Openness. The supposed Agreeableness did not have a significant effect on Travel intention. This study contributes to understanding the respondents' behavior during pandemic of COVID-19, and their responses to the crisis according to their personality traits might have practical implications in the travel sector.
\end{abstract}

Keywords: personality traits; travel intention; COVID-19; pandemic; travel anxiety

\section{Introduction}

The pandemic caused by COVID-19 has been spreading throughout China and worldwide; the pandemic danger has not only threatened lives due to infection, but has also brought about enormous psychological tension [1]. Besides adverse effects on peoples' physical and mental health, the outbreak of COVID-19 has proven to be an economic problem [2]. All the sectors, without exception, suffer massive damage, but the extent of the damage varies among sectors and countries [3]. Compared to SARS which spread to more than 20 nations in 2003, more people are infected by the new coronavirus [4-6]. With the aim to protect the population and prevent the spread of the pandemic, drastic measures were taken by every country in the world. All the countries closed schools, borders, and stopped production and trade. These changes had effects on all the areas of economy, including the tourism industry $[5,7,8]$. There are too many ways in which pandemics can affect tourism and hospitality industry. Primarily, restrictions that are related to travel have a negative impact on economy in general, not only on the tourism and hospitality industry. Travel restrictions which have been implemented to limit the spread of the new coronavirus and to protect residents' health $[9,10]$ made it difficult for individuals to move. As stated by 
Fuchs and Reichel [11], in the tourism industry there are several types of risks which need to be considered and one of them is physical/health risk which includes issues related to food safety, accidents, epidemics, etc. Although there has been considerable emphasis on the ways to identify those who are infected with COVID-19, determining the mental care requirements of those affected by the coronavirus has been quite disregarded [12]. This is unexpected considering the fact that major catastrophes, particularly those involving contagious illnesses, frequently produce waves of anxiety, which are identified to bring about enormous disturbances in the psychological welfare and persons' behavior [13].

Individuals perceive danger from COVID-19 as extremely realistic and there are many reasons individuals are frightened, such as losing a job, being very ill or spreading virus to people from the immediate environment, being held accountable for their suffering and death, as well as about the overall financial losses which are linked with the virus [14,15]. Because of the worldwide epidemics, the option to visit destinations includes many potential threats in the perception of tourists. This is due to the insecurity regarding the situations that tourists would face in the tourist destination, and even more, because of the possible adverse effects associated with the decision chosen [16]. Taylor [17] stated that anxiety is a determining factor of behavior. For instance, the same author stated that, at the point when individuals become more anxious with regard to the infection, they tend to keep a high degree of personal cleanliness, more social distancing, and become more likely to get vaccinated when available. To keep away from becoming anxious and from its adverse consequences, potential travelers assess risks related to purchasing decisions.

Several factors, including the person's characteristics and resources, might impact an individual's mental and behavioral reactions to the pandemic [18,19], as indicated by earlier research that has emphasized the considerable role of personality traits on stress reactions $[20,21]$. As a result, personality traits can influence a person's reactions to life circumstances by impacting cognitive judgments, the feelings associated with them, and the techniques employed to control those emotional signals [22,23].

Within this frame of reference, it is important to understand people's behavior and their anxiety regarding traveling during the pandemic of COVID-19. For that reason, the aim of this study is to investigate the relationship between the fear of COVID-19, travel anxiety, and travel intention, and to examine the impact of personality traits on the fear of COVID-19, travel anxiety, and travel intentions. The study emphasizes the key role of personality traits in the intention to visit a tourist destination during the COVID-19 pandemic, under circumstances in which fear of illness and anxiety occur during travel.

\section{Literature Review}

Fear. During epidemics, the number of individuals who are impacted by mental illness is usually larger than the number of persons who are infected. Previous disasters have demonstrated that mental health consequences can endure longer and have a higher incidence than the pandemic itself, and that the psychological and economic consequences can be incalculable when considered in diverse situations [24]. According to Steimer [25], fear is an innate adaptive emotional reaction that happens during a stressful situation in response to a specific external threat. In the context of a pandemic, fear can be a motivator for individuals to engage in protective and preventive behavior in order to avoid infection and follow recommendations. Intense and uncontrolled fear, on the other hand, can have a number of psychological and behavioral repercussions [26-29]. Excessive fear can impair complicated information processing and socializing. One of most typical reactions during pandemics is the fear of the virus infection $[30,31]$ which can contribute to health anxiety, concern, phobias, and psychological discomfort [32-35].

Travel anxiety. As stated by Arkin and Ruck [36], anxiety can be defined as a condition of suspense, tension, and fear that stems from a widespread perception of danger. Anxiety, according to researchers, differs from anger and sadness, because it stems from fear [37]. Anxiety develops when an individual is concerned about the possibly adverse effects of a future occurrence and believes they are unable to change the course of events [38]. As 
has been suggested, it stems from threats such as crime, bloodshed, terrorism, political upheaval, illnesses, unpredictable atmosphere, etc. [39]. The neurological disease linked to the COVID-19 epidemic has now been given a name: coronaphobia, or coronavirus anxiety [40]. Individuals engage in avoidance activities in order to escape the repercussions. There is a strong aversion to taking public transport, touching any surface, being in both open (markets, beaches, stadiums) and enclosed spaces (hotels, retail malls, movie theaters, indoor stadiums), attending public gatherings, and standing in line [41].

Travel intention. Intention to travel refers to visitors' desires or intentions when planning a journey. In terms of shaping impressions of tourism destinations, information sources are considered to be more significant than personal factors [42]. The perceived danger and safety perceptions strongly affect travel plans. When risk makes the destination less secure, possible travelers have several options, including (1) continuing with their trip plans, (2) altering the choice of a trip destination, (3) adjusting their trip behavior, and (4) getting further information if they intend to continue with their trip plans $[43,44]$.

Several studies confirmed a positive relation between fear of COVID-19 and anxiety $[30,45,46]$. Anxiety and fear related to COVID-19 had different implications for individuals' daily routines, particularly concerning traveling $[47,48]$ and the hospitality industry $[49,50]$. In the examination conducted among the Germans, neuroticism was found as a predictor of higher anxiety and adverse effects during the pandemic [51]. According to Qiu et al. [33], the suggested coronavirus preventive measures, such as self-isolation and house quarantine, have a detrimental impact on person's mental health, generating illnesses such as anxiety, depression, and panic disorder. Furthermore, Zhang et al. [52] indicate that individuals who recovered from COVID-19, those in quarantine, and the general population, all acquired anxiety symptoms and depression. Additionally, persons who were afflicted by the COVID-19 pandemic experienced psychological discomfort and required psychological care [53]. Gajić et al. [54] found influence of fear of COVID-19 on decision to travel.

Personality traits. In several studies it has been found that the type of personality can affect the person's behavior, as well as the attitudes and decision-making processes related to different situations, such as customer purchasing, stock market investing, taking more risk, and making professional and personal decisions [55-57]. During a pandemic, variability in general patterns of ideas, emotions, and behaviors may influence how people react and behave.

Extroversion alludes to the propensity to be active, to incline toward enormous gatherings and social occasions, and to be confident, dynamic, and loquacious. Individuals with high levels of extraversion tend to be extremely lively, joyful and optimistic [58-60]. Extroversion also reflects the desire to be sociable, lively and confident, as well as the need to find energy. This might be one of the reasons why extroversion has been found to be negatively related with stress and anxiety [61]. Individuals with higher levels of extroversion, like everyone else, have problems, but they may be able to adjust to life's pressures more successfully than others, reducing the negative consequences of having difficulties [62].

Neuroticism is a personality trait that makes people more prone to emotional instability and self-consciousness [63]. Individual differences in negative emotionality are referred to as neuroticism $[64,65]$ and predict a variety of negative consequences, which can include low subjective well-being $[66,67]$ and lower physical and mental health $[68,69]$. Neuroticism has been shown to be positively linked with perceived stress by many researchers [61]. Individuals with a high level of neuroticism are susceptible to unpleasant emotions such as sadness, anxiety, or rage, and they are impulsive and self-conscious [70,71]. Additionally, neuroticism is commonly connected with the impression of negative, stressful, or unpleasant experiences [72], suggesting that it may influence how individuals perceive and assess coronavirus.

Conscientiousness is the disposition to resist urges and temptations. As a result, people with high levels of conscientiousness tend to strive for competence and dutifulness [63]. 
Furthermore, these people are reported to be very intentional, strong-willed, and resolute. Additionally, people with high level of conscientiousness are typically connected with achievements in the field of education and occupation; nevertheless, these people may be lured to irritating fastidiousness, compulsive neatness, and workaholic behavior [58-60]. Individuals' levels of conscientiousness are linked to how they manage, regulate and show sensitivity. Being goal-oriented, persistent, obedient, organized, and adhering to norms and standards are all traits associated with a high conscientiousness score [73].

Openness is a cognitive inclination toward aesthetics and creativity [63,74]. Individuals with high levels of openness tend to be inquisitive about their both inner and exterior environments. These people are known to have an active imagination, aesthetic sensitivity, and awareness of inner emotions, as well as a preference for a wide range of objects, intellectual curiosity, and autonomous judgment. These people are typically unique, prepared to challenge authority, and eager to discuss new ethical and social concepts [58-60]. Individuals with high levels of openness are inquisitive, tolerant, culturally engaged, and eager to try something new [75].

Agreeableness is described as the desire to be altruistic, sensitive to others and ready to assist them, with the expectation that others would be as helpful in return [58-60]. Prosocial behavior and volunteerism are thought to be linked to agreeableness [76]. Additionally, individuals with high levels of agreeability are kind, sensitive, helpful, and willing to put others' needs ahead of their own [73]. Agreeableness tends to be linked to gratitude [77] and forgiveness [78].

Personality characteristics are among the factors that determine the types of behavior people take. Existing research found a link between personality traits and many types of behavior. Personality has a notable influence on cooperative behavior [79], such as obeying group norms and assisting group members [80]. In terms of health behavior, there are connections with personality traits.

Higher scores of neuroticism are often correlated with concern for health [81]. Additionally, people with lower levels of extroversion, agreeableness, and openness to experience are more likely to prevent infectious illnesses [82]. Bogg and Roberts [83] found a connection between conscientiousness and healthy behaviors, such as avoiding hazardous sexual activity and substance misuse. Moreover, the perception of negative, stressful, and disagreeable situations is usually linked to neuroticism [72], making it possible to influence peoples' perception and evaluation of COVID-19. Furthermore, Maritz et al. [84] found positive effects of extraversion and conscientiousness on travel intention.

In the context of the coronavirus pandemic, a plethora of research investigated the correlation between personality traits and various behaviors and emotions brought about by COVID-19. For example, people with strong neuroticism are generally more concerned about COVID-19 [85] and report higher stress levels during the outbreak [86], while persons with higher levels of conscientiousness are more prone to engage in hoarding behavior [87]. Besides this, people high in conscientiousness are more likely to behave in accordance with the suggestions [88]. With respect to personality traits, Nazari et al. [35] found positive association between fear of coronavirus and neuroticism, while extroversion negatively correlated with fear of COVID-19.

Mirhaghi and Sarabian [61] found an inverse association between agreeableness and stress. It is worth noting that, in earlier research referring to the coronavirus pandemic $[89,90]$, agreeableness was linked to reduced levels of stress, anxiety, and symptoms of depression. Additionally, lower levels of extroversion and greater levels of conscientiousness are associated with a stronger willingness to wash hands and apply social distance. Higher levels of openness was linked to better hygiene, whereas individuals with lower levels of extroversion and higher levels of neuroticism, conscientiousness, and agreeableness showed better hygiene practice and respecting social distance [91]. Contrary to neuroticism, lower levels of anxiety brought about by COVID-19 were associated with higher levels of conscientiousness [92,93].

In line with these arguments and previous evidence, we suggest the next 18 hypotheses: 
Hypothesis 1 (H1). Fear of COVID-19 positively affects travel anxiety.

Hypothesis 2 (H2). Fear of COVID-19 negatively affects travel intention.

Hypothesis 3 (H3). Travel anxiety negatively affects travel intention.

Hypothesis 4 (H4). Extroversion negatively affects fear of COVID-19.

Hypothesis 5 (H5). Agreeableness negatively affects fear of COVID-19.

Hypothesis 6 (H6). Conscientiousness positively affects fear of COVID-19.

Hypothesis 7 (H7). Neuroticism positively affects fear of COVID-19.

Hypothesis 8 (H8). Openness negatively affects fear of COVID-19.

Hypothesis 9 (H9). Extroversion negatively affects travel anxiety.

Hypothesis 10 (H10). Agreeableness negatively affects travel anxiety.

Hypothesis 11 (H11). Conscientiousness positively affects travel anxiety.

Hypothesis 12 (H12). Neuroticism positively affects travel anxiety.

Hypothesis 13 (H13). Openness negatively affects travel anxiety.

Hypothesis 14 (H14). Extroversion positively affects travel intention.

Hypothesis 15 (H15). Agreeableness positively affects travel intention.

Hypothesis 16 (H16). Conscientiousness negatively affects travel intention.

Hypothesis 17 (H17). Neuroticism negatively affects travel intention.

Hypothesis 18 (H18). Openness positively affects travel intention.

The expected relationships and hypotheses are presented in Figure 1.

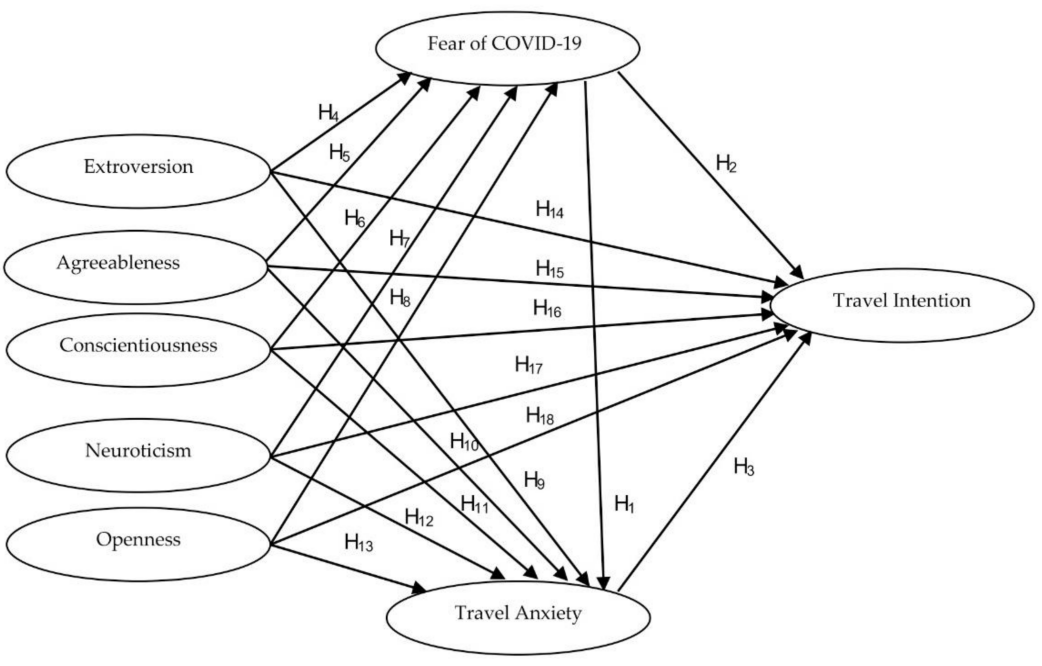

Figure 1. Proposed model of research. 


\section{Materials and Methods}

\subsection{Instruments}

The questionnaire used in this study was composed from several scales used in previous research which has demonstrated validity and significance of the assessment scales. All the items applied in this study were back-translated in Serbian by the authors and the accuracy of translation was verified. For assessing the level of agreement, respondents marked answers from 1-strongly disagree to 5-strongly agree (5-point Likert scale).

Sociodemographic variables: Questions referring to sociodemographic characteristics were placed in the first part of the questionnaire. Examinees were asked to provide answers about their gender, age, marital status, education level, and monthly incomes. The last question referred to their traveling during the pandemic.

Fear of COVID-19 (F) was measured by a 7-item scale adopted from Ahorsu et al. [30] and Luo and Lam [45]. The scale included items such as "My heart races or palpitates when I think about getting COVID-19". The Fear of COVID-19 total score also suggests that this is a good psychometric tool that can be compared by gender and all age groups and can be used to assess and mitigate the fear of pandemics among individuals [30].

Travel Anxiety (TA): Six-item model adopted from Wachyuni and Kusumaningrum [94] assessed the respondents' concerns related to traveling after proclaiming the pandemic of COVID-19 to be over. An example of the item is "I feel an irregular heartbeat when I think of going on a tour during the pandemic".

Travel Intention (TI): Three-item scale was used for measuring travel intention of the respondents. This scale was adopted from Luo and Lam's study [36]. In the original study, travel intention referred to traveling to travel bubble destination. For the purpose of this study, the items were modified. Considering the current situation of spreading COVID-19 and the number of new cases in the countries of the region, the authors decided to examine travel intention to countries with the similar situation as in Serbia. Based on that, the example of the item is "I would like to travel to countries with a similar epidemiological situation in the future".

BFI-Five major types of personality traits have been built into commonly recognized and useful assessments for investigating, classifying and predicting behavior. Many of these scales are based on the five-factor model, which is often known as the Big-Five [95-97]. The BFI self-report (BFPTSQ) [98] measure involves 44 items and evaluates Agreeableness (A), Extroversion (E), Conscientiousness (C), Openness (O), and Neuroticism (N).

\subsection{Procedure}

The data were collected through a standard paper-and-pen survey, utilizing a convenient method for sampling. The survey was conducted from December 2020 until July 2021, and the participation was anonymous and voluntary. Adult citizens of the Republic of Serbia (18 and older) were included in the research. Data collecting was conducted in larger city centers of Serbia (Belgrade, Novi Sad, Niš, Kragujevac, Subotica, Zaječar, Čačak, Leskovac, Novi Pazar, and Vranje). So as to obtain a relevant sample that included the citizens from all the parts of the country, the city centers from all the regional entities of the Republic of Serbia, excluding Kosovo and Metohija, were chosen [99]. For conducting the survey, 20 students from the Faculty of Sciences, University of Novi Sad, were engaged. There was a total of 1500 survey questionnaires distributed (150 in each city). The questionnaires were distributed in shopping centers and hospitality facilities. Of the total number, 987 of them were properly filled out (the response rate of $65.8 \%$ ). The average time to fill out the questionnaire was $15 \mathrm{~min}$. These data were processed by R and RStudio (lavaan, semPlot, and semTools packages) which was used for the CFA and SEM analyses.

\section{Results}

\subsection{Study Sample}

The sample consisted of 987 participants. There was a higher number of women in the sample (55.9\%), while the average age of the participants was 35.78 (age range 18-76). 
Most of the respondents have an income in the range 40,001-50,000 RSD (33.2\%), hold a BSc degree (47.5\%), and are married (45.8\%). When it comes to traveling during COVID-19, $64.8 \%$ said that they did not travel during the pandemic (Table 1).

Table 1. The sample characteristics $(\mathrm{N}=987)$.

\begin{tabular}{|c|c|c|c|}
\hline Gender (\%) & \multicolumn{3}{|c|}{ Education (\%) } \\
\hline Male & 44.1 & Secondary/High school & 28.9 \\
\hline \multirow[t]{3}{*}{ Female } & 55.9 & Undergraduate/BSc degree & 47.5 \\
\hline & & Graduate/MSc degree & 17.4 \\
\hline & & Graduate/PhD degree & 6.2 \\
\hline \multirow{6}{*}{ Age Average: 35.78} & \multirow{6}{*}{ Std. 15.41} & \multicolumn{2}{|c|}{ Marital status (\%) } \\
\hline & & Single & 17.2 \\
\hline & & In a relationship & 29.6 \\
\hline & & Married & 45.8 \\
\hline & & Divorced & 4.0 \\
\hline & & Widow/widower & 3.4 \\
\hline \multicolumn{2}{|c|}{ Monthly income (in Serbian dinars-RSD) (\%) } & \multicolumn{2}{|c|}{ Traveling during COVID-19 (\%) } \\
\hline Below 30,000 & 8.4 & Yes & 35.2 \\
\hline $30,001-40,000$ & 20.9 & No & 64.8 \\
\hline $40,001-50,000$ & 33.2 & & \\
\hline $50,001-60,000$ & 26.7 & & \\
\hline
\end{tabular}

\subsection{Measurement Model Validity—Confirmatory Factorial Analysis}

The latent factors measurement model was estimated to check for innate construct validity and reliability using Confirmatory factorial analysis (CFA). Table 2 shows the results of the measurement model estimation. According to the results, all fit indices $(\mathrm{TLI}=0.987 ; \mathrm{CFI}=0.986 ; \mathrm{RMSEA}=0.075 ; \mathrm{SRMR}=0.062)$ revealed a satisfactory fit.

Table 2. CFA results.

\begin{tabular}{|c|c|c|c|c|c|c|}
\hline Factors & Items & $\beta$ & $t$ Value & $\alpha$ & AVE & CR \\
\hline \multirow{8}{*}{$\begin{array}{l}\text { Extroversion } \\
\text { (E) }\end{array}$} & I am talkative. & 0.881 & $* *$ & \multirow{8}{*}{\multicolumn{3}{|c|}{0.9400 .6820 .780}} \\
\hline & I am reserved. * & 0.953 & 56.379 & & & \\
\hline & I am full of energy. & 0.876 & 54.088 & & & \\
\hline & I generate a lot of enthusiasm. & 0.893 & 49.273 & & & \\
\hline & I tend to be quiet. * & 0.674 & 32.990 & & & \\
\hline & I have an assertive personality. & 0.784 & 40.279 & & & \\
\hline & I am sometimes shy, inhibited. * & 0.718 & 38.829 & & & \\
\hline & I am outgoing, sociable. & 0.790 & 42.576 & & & \\
\hline \multirow{9}{*}{$\begin{array}{c}\text { Agreeableness } \\
\text { (A) }\end{array}$} & I tend to find fault with others. * & 0.824 & $* *$ & \multirow{9}{*}{\multicolumn{3}{|c|}{0.8950 .5140 .723}} \\
\hline & I am helpful and unselfish with others. & 0.839 & 34.719 & & & \\
\hline & I start quarrels with others. * & 0.698 & 31.743 & & & \\
\hline & I have a forgiving nature. & 0.753 & 30.952 & & & \\
\hline & I am generally trusting. & 0.579 & 21.837 & & & \\
\hline & I can be cold and aloof. & 0.682 & 25.306 & & & \\
\hline & I am considerate and kind to almost everyone. & 0.689 & 28.633 & & & \\
\hline & I am sometimes rude to others. ${ }^{*}$ & 0.675 & 26.087 & & & \\
\hline & I like to cooperate with others. & 0.674 & 23.112 & & & \\
\hline
\end{tabular}


Table 2. Cont.

\begin{tabular}{|c|c|c|c|c|c|}
\hline Factors & Items & $\beta$ & $t$ Value & AVE & CR \\
\hline \multirow{9}{*}{$\begin{array}{l}\text { Conscientiousness } \\
\text { (C) }\end{array}$} & I do a job thoroughly. & 0.617 & ** & \multirow{9}{*}{\multicolumn{2}{|c|}{0.8980 .5120 .718}} \\
\hline & I can be somewhat careless. * & 0.730 & 21.504 & & \\
\hline & I am a reliable worker. & 0.853 & 21.987 & & \\
\hline & I tend to be disorganized. * & 0.700 & 20.244 & & \\
\hline & I tend to be lazy. * & 0.661 & 18.094 & & \\
\hline & I persevere until the task is finished. & 0.619 & 18.712 & & \\
\hline & I do things efficiently. & 0.841 & 20.514 & & \\
\hline & I make plans and follow through with them. & 0.683 & 19.898 & & \\
\hline & I am easily distracted. * & 0.697 & 20.575 & & \\
\hline \multirow{8}{*}{$\begin{array}{l}\text { Neuroticism } \\
(\mathrm{N})\end{array}$} & I am depressed, blue. & 0.539 & ** & \multirow{8}{*}{\multicolumn{2}{|c|}{0.9040 .5790 .826}} \\
\hline & I am relaxed, handle stress well. * & 0.869 & 21.105 & & \\
\hline & I can be tense. & 0.764 & 20.484 & & \\
\hline & I worry a lot. & 0.792 & 19.936 & & \\
\hline & I am emotionally stable, not easily upset. * & 0.816 & 21.800 & & \\
\hline & I can be moody. & 0.786 & 21.490 & & \\
\hline & I remain calm in tense situations. ${ }^{*}$ & 0.739 & 20.224 & & \\
\hline & I get nervous easily. & 0.741 & 21.872 & & \\
\hline \multirow{10}{*}{$\begin{array}{l}\text { Openness } \\
(\mathrm{O})\end{array}$} & I am original, comes up with new ideas. & 0.896 & ** & \multirow{10}{*}{\multicolumn{2}{|c|}{0.9540 .7010 .899}} \\
\hline & I am curious about many different things. & 0.774 & 50.795 & & \\
\hline & I am ingenious, a deep thinker. & 0.790 & 42.505 & & \\
\hline & I have an active imagination. & 0.863 & 60.709 & & \\
\hline & I am inventive. & 0.864 & 55.535 & & \\
\hline & I value artistic, aesthetic experiences. & 0.787 & 45.186 & & \\
\hline & I prefer work that is routine. ${ }^{*}$ & 0.881 & 55.316 & & \\
\hline & I like to reflect, play with ideas. & 0.872 & 66.490 & & \\
\hline & I have few artistic interests. * & 0.865 & 58.944 & & \\
\hline & I am sophisticated regarding art, music, or literature. & 0.769 & 37.603 & & \\
\hline \multirow{7}{*}{$\begin{array}{l}\text { Fear of } \\
\text { COVID-19 } \\
\quad(\mathrm{F})\end{array}$} & I am afraid of the novel coronavirus the most. & 0.908 & ** & \multirow{7}{*}{\multicolumn{2}{|c|}{0.9680 .8300 .941}} \\
\hline & $\begin{array}{l}\text { It makes me uncomfortable to think about } \\
\text { novel coronavirus. }\end{array}$ & 0.896 & 99.470 & & \\
\hline & My hands become sweaty when I think about COVID-19. & 0.985 & 99.296 & & \\
\hline & I am afraid of losing my life because of COVID-19. & 0.923 & 95.393 & & \\
\hline & $\begin{array}{l}\text { When watching news and stories about novel } \\
\text { coronavirus on social media or } \\
\text { any other media (i.e., TV, radio), I become nervous } \\
\text { or anxious. }\end{array}$ & 0.866 & 82.147 & & \\
\hline & $\begin{array}{l}\text { I cannot sleep because I am worried about getting the } \\
\text { novel coronavirus. }\end{array}$ & 0.917 & 99.315 & & \\
\hline & $\begin{array}{l}\text { My heart races or palpitates when I think about getting } \\
\text { COVID-19. }\end{array}$ & 0.882 & 71.290 & & \\
\hline
\end{tabular}


Table 2. Cont.

\begin{tabular}{|c|c|c|c|c|c|c|}
\hline Factors & Items & $\beta$ & $t$ Value & $\alpha$ & AVE & CR \\
\hline \multirow{6}{*}{$\begin{array}{l}\text { Travel Anxiety } \\
\text { (TA) }\end{array}$} & $\begin{array}{l}\text { I feel uncomfortable after thinking of going on a tour } \\
\text { during a pandemic. }\end{array}$ & 0.933 & ** & \multirow{6}{*}{\multicolumn{3}{|c|}{0.8540 .8460 .962}} \\
\hline & $\begin{array}{l}\text { I feel that my body is not fit after planning tourism } \\
\text { activities during the pandemic. }\end{array}$ & 0.868 & 59.333 & & & \\
\hline & I was afraid to go on a tour during the pandemic. & 0.919 & 74.524 & & & \\
\hline & I will panic when I travel during COVID-19. & 0.842 & 66.922 & & & \\
\hline & I sweat after deciding to travel during a pandemic. & 0.735 & 81.266 & & & \\
\hline & $\begin{array}{l}\text { I feel an irregular heartbeat when I think of going on a } \\
\text { tour during the pandemic. }\end{array}$ & 0.899 & 82.325 & & & \\
\hline \multirow{3}{*}{$\begin{array}{l}\text { Travel Intention } \\
\qquad(\mathrm{TI})\end{array}$} & $\begin{array}{l}\text { I would like to travel to countries with the similar } \\
\text { epidemiological situation in the future. }\end{array}$ & 0.873 & ** & \multirow{3}{*}{\multicolumn{3}{|c|}{0.8840 .8540 .942}} \\
\hline & $\begin{array}{l}\text { I prefer to travel to countries with the similar } \\
\text { epidemiological situation compared with other forms } \\
\text { of tourism. }\end{array}$ & 0.918 & 41.679 & & & \\
\hline & $\begin{array}{l}\text { I will recommend countries with the similar } \\
\text { epidemiological situation to relatives or friends. }\end{array}$ & 0.929 & 26.530 & & & \\
\hline
\end{tabular}

Notes: ${ }^{*}$ Denotes reverse-scored items; ${ }^{* *}$ Items fixed to 1 in CFA; $\beta$-Std. regression weights; $\alpha$-Cronbach's alpha; CR-Composite reliability; AVE-Average variance expected.

The reliability of the scale was assessed through average variance extracted (AVE) indices and composite reliability (CR) (Table 2). The convergent validity of each dimension was examined by calculating the score of the average variance extracted (AVE). A substantial convergent validity is achieved when all item-to-factor loadings are significant and the AVE score is higher than 0.50 within each dimension [100]. The composite reliability values for the latent factors exhibited satisfactory levels exceeding the recommended minimum value of $0.7[101,102]$. The results indicate that all the dimensions had AVE higher than 0.50 and CR higher than 0.70 (Table 2), which indicates good convergent validity. The results indicate that the alpha coefficients of the nine factors, with radius from 0.854 to 0.968 , which demonstrates that the scales of the questionnaire, had considerable reliability [103] (Table 2).

The discriminant validity was assessed using Fornell and Larcker [100] by comparing the square root of each AVE in the diagonal with the correlation coefficients for each construct in the relevant rows and columns (Table 3). The AVE values' square roots have a greater value than the correlations with other latent constructs. Thus, the results confirm that all the dimensions have sufficient discriminant validity [81], which is shown in Table 3.

Table 3. Discriminant validity assessment.

\begin{tabular}{|c|c|c|c|c|c|c|c|c|}
\hline & $\mathbf{E}$ & A & C & $\mathbf{N}$ & O & $\mathbf{F}$ & TA & TI \\
\hline $\mathrm{E}$ & 0.825 & & & & & & & \\
\hline A & $0.493^{* *}$ & 0.717 & & & & & & \\
\hline $\mathrm{C}$ & $-0.557^{* *}$ & $-0.260^{* *}$ & 0.715 & & & & & \\
\hline $\mathrm{N}$ & $-0.791^{* *}$ & $-0.558^{* *}$ & $0.648^{* *}$ & 0.761 & & & & \\
\hline $\mathrm{O}$ & $0.790^{* *}$ & $0.499 * *$ & $-0.521^{* *}$ & $-0.754^{* *}$ & 0.837 & & & \\
\hline $\mathrm{F}$ & $-0.620^{* *}$ & $-0.474^{* *}$ & 0.599 ** & $0.664^{* *}$ & $-0.582 * *$ & 0.911 & & \\
\hline TA & $-0.558^{* *}$ & $-0.423^{* *}$ & $0.545^{* *}$ & 0.592 ** & $-0.535^{* *}$ & $0.804^{* *}$ & 0.920 & \\
\hline $\mathrm{TI}$ & $0.757^{* *}$ & $0.398^{* *}$ & $-0.625^{* *}$ & $-0.733^{* *}$ & $0.718^{* *}$ & $-0.566^{* *}$ & $-0.515^{* *}$ & 0.854 \\
\hline
\end{tabular}




\subsection{Results of the Path Model}

The variety of forms in the proposed model were assessed and the overall fit of the model was considered satisfactory for the observed sample (CFI $=0.951$; TLI $=0.946$; RMSEA $=0.051$; SRMR $=0.079 ; \mathrm{df}=18, p<0.000$ ). Fit indices were acceptable for addressing the hypothesized interrelations between each latent factor.

Table 4 shows the outcomes of the hypothesized interactions in the proposed model. Fear of COVID-19 on Travel anxiety (H1) indicated significant and positive impact $(\beta=0.693$, $p<0.000)$. Fear of COVID-19 $(\beta=0.011, p=0.759)$ and Travel anxiety $(\beta=-0.006$, $p=0.866)$ were not found to negatively affect the Travel intention ( $\mathrm{H} 2$ and $\mathrm{H} 3)$. Extroversion $(\beta=-0.158, p=0.000)$ and Agreeableness $(\beta=-0.176, p=0.000)$ had a significant negative effect, and Conscientiousness ( $\beta=0.307, p=0.000)$ and Neuroticism $(\beta=0.195$, $p=0.000$ ) had a significant and positive influence on Fear of COVID-19, thus supporting H4, $\mathrm{H} 5, \mathrm{H6}$, and H7. H8 was not supported, indicating that Openness did not have a significant negative impact on Fear of COVID-19 $(\beta=-0.064, p<0.145)$. Extroversion $(\beta=-0.025$, $p=0.516)$, Agreeableness $(\beta=-0.035, p=0.146)$, and Openness $(\beta=-0.063, p=0.122) \mathrm{did}$ not have a significant effect on Travel anxiety, so H9, H10, and $\mathrm{H} 13$ cannot be confirmed. H11 and H12 were supported, indicating that Conscientiousness ( $\beta=0.078, p=0.008)$ and Neuroticism $(\beta=0.210, p=0.002)$ showed a significant positive effect on Travel anxiety. Extroversion $(\beta=0.340, p=0.000)$ and Openness $(\beta=0.222, p=0.000)$ had a significant positive effect on Travel intention. These results support H14 and H18. Further, Conscientiousness $(\beta=-0.216, p=0.000)$ and Neuroticism $(\beta=-0.180, p=0.000)$ indicated a significant negative impact on Travel intention that confirmed H16 and H17. The supposed Agreeableness did not have a significant effect on Travel intention $(\beta=-0.034, p=0.152)$, thus we rejected H15. The results of the path model are shown in Figure 2.

Table 4. The results of model (standardized regression weights).

\begin{tabular}{|c|c|c|c|c|c|}
\hline Hypothesized Paths & $\beta$ & S.E. & $z$-Value & $p$-Value & Hypothesis \\
\hline $\mathrm{H}_{1}$ : Fear of COVID-19 $\rightarrow$ Travel anxiety $(+)$ & 0.693 & 0.031 & 22.085 & 0.000 & Supported \\
\hline $\mathrm{H}_{2}:$ Fear of COVID-19 $\rightarrow$ Travel intention $(-)$ & 0.011 & 0.046 & 0.307 & 0.759 & Not supported \\
\hline $\mathrm{H}_{3}$ : Travel anxiety $\rightarrow$ Travel intention (-) & -0.006 & 0.043 & -0.169 & 0.866 & Not supported \\
\hline $\mathrm{H}_{4}:$ Extroversion $\rightarrow$ Fear of COVID-19 $(-)$ & -0.158 & 0.056 & -3.490 & 0.000 & Supported \\
\hline $\mathrm{H}_{5}:$ Agreeableness $\rightarrow$ Fear of COVID-19 $(-)$ & -0.176 & 0.054 & -6.088 & 0.000 & Supported \\
\hline $\mathrm{H}_{6}$ Conscientiousness $\rightarrow$ Fear of COVID-19 (+) & 0.307 & 0.057 & 9.246 & 0.000 & Supported \\
\hline $\mathrm{H}_{7}:$ Neuroticism $\rightarrow$ Fear of COVID-19 (+) & 0.195 & 0.061 & 3.809 & 0.000 & Supported \\
\hline $\mathrm{H}_{8}:$ Openness $\rightarrow$ Fear of COVID-19 $(-)$ & -0.064 & 0.054 & -1.459 & 0.145 & Not supported \\
\hline $\mathrm{H}_{9}:$ Extroversion $\rightarrow$ Travel anxiety $(-)$ & -0.025 & 0.047 & -0.650 & 0.516 & Not supported \\
\hline $\mathrm{H}_{10}:$ Agreeableness $\rightarrow$ Travel anxiety $(-)$ & -0.035 & 0.045 & -1.455 & 0.146 & Not supported \\
\hline $\mathrm{H}_{11}$ : Conscientiousness $\rightarrow$ Travel anxiety $(+)$ & 0.078 & 0.051 & 2.652 & 0.008 & Supported \\
\hline $\mathrm{H}_{12}:$ Neuroticism $\rightarrow$ Travel anxiety $(+)$ & 0.210 & 0.049 & 2.987 & 0.002 & Supported \\
\hline $\mathrm{H}_{13}:$ Openness $\rightarrow$ Travel anxiety $(-)$ & -0.063 & 0.041 & -1.548 & 0.122 & Not supported \\
\hline $\mathrm{H}_{14}:$ Extroversion $\rightarrow$ Travel intention $(+)$ & 0.340 & 0.061 & 8.897 & 0.000 & Supported \\
\hline $\mathrm{H}_{15}:$ Agreeableness $\rightarrow$ Travel intention $(+)$ & -0.034 & 0.057 & -1.431 & 0.152 & Not supported \\
\hline $\mathrm{H}_{16}:$ Conscientiousness $\rightarrow$ Travel intention $(-)$ & -0.216 & 0.073 & -6.584 & 0.000 & Supported \\
\hline $\mathrm{H}_{17}:$ Neuroticism $\rightarrow$ Travel intention $(-)$ & -0.180 & 0.067 & -4.061 & 0.000 & Supported \\
\hline $\mathrm{H}_{18}:$ Openness $\rightarrow$ Travel intention $(+)$ & 0.222 & 0.059 & 5.902 & 0.000 & Supported \\
\hline
\end{tabular}




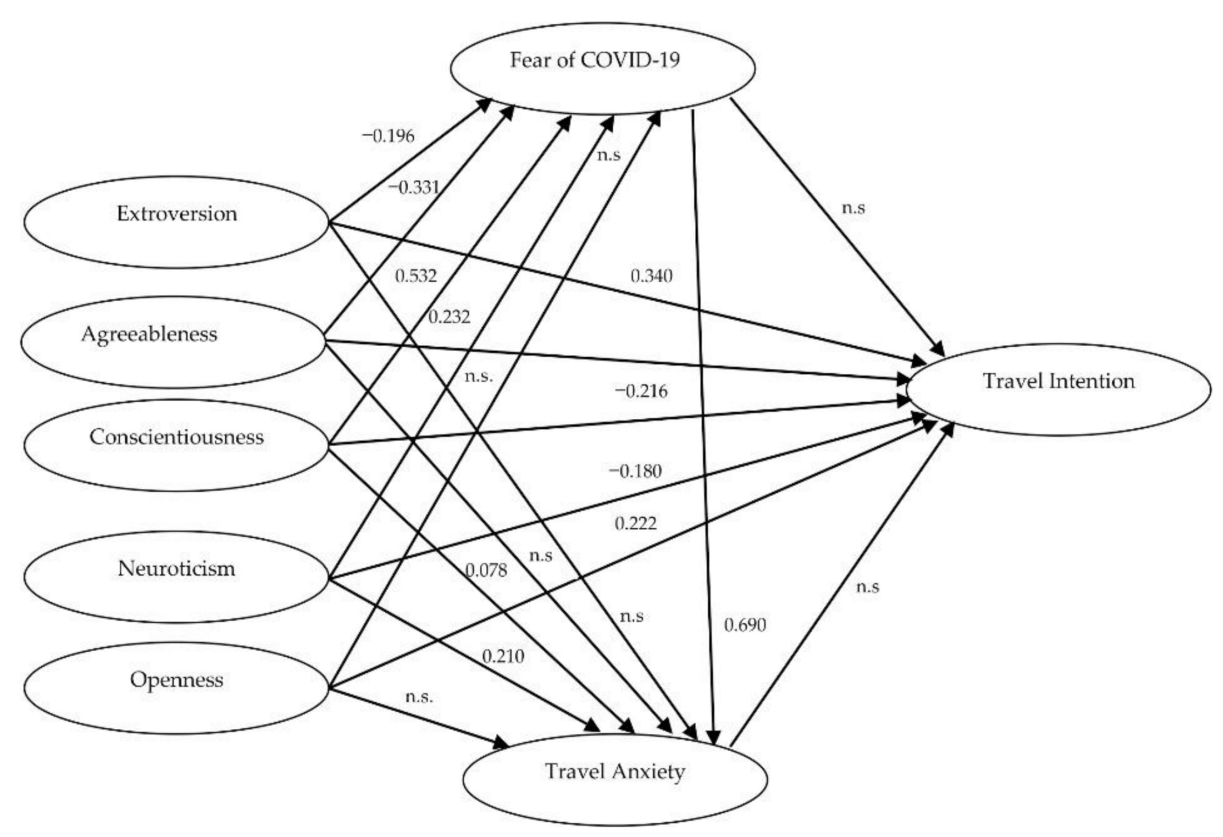

Figure 2. The results of the path model based on standardized regression weights.

\section{Discussion}

The study results provided a better insight into people's responses to the pandemic depending on personality traits. Individuals' behavior during the pandemic might be predicted if we have information about their personality characteristics.

Although fear and anxiety are considered as two distinct feelings [104], many studies found a positive relationship between them $[30,45,46]$. Based on that, it was assumed that increase in Fear of COVID-19 will increase Travel anxiety (H1). The results of the study confirm the authors' expectations and gave support for $\mathrm{H} 1$. Although it was expected to find a negative connection between Fear of COVID-19 and Travel intention, the results show no notable connection between these two variables. Even though these results do not provide support for H2, they confirm the results of Luo and Lam's [45] study. Therefore, there is no indication that fear related to COVID-19 can decrease people's intention to travel. Perhaps it can be explained through the fact that COVID-19 is present worldwide and the risk of getting infected is possible in their countries as well as in other tourist destinations. Furthermore, based on the existing literature, it was expected to find a negative correlation between Travel anxiety and Travel intention [45,105], but the effects of Travel anxiety on Travel intention are not significant, which rejected H3. Due to the increase in the number of people infected by COVID-19, on 15 March 2020, a state of emergency was declared in the territory of the Republic of Serbia, which was revoked on 6 May 2020 [106]. After the lifting of the restrictive measures and lockdown, the number of visitors in tourist destinations in Serbia increased, and the number of domestic tourists rose by $26.66 \%$ in the first six months, compared to the same period in the previous year. The fastest recovery after the declaration of the state of emergency was recorded in spa and mountain tourist centers in Serbia, which means that the prevailing motive was relaxation, leisure, sports, and recreation [107,108]. The research carried out by Abdullah [109] confirmed that the tourists decided to travel stirred by "revolt and boredom" during the pandemic because they were excluded from social activities during the period of isolation. The aforementioned implies that although there was fear of infection with COVID-19, it did not affect the intention to travel among the examinees in the observed sample.

Extroversion. Considering the fact that the characteristics of Extroversion can help in recuperating from negative effects of stressful situations [110], it was expected to find a negative relationship between Extroversion and Fear of COVID-19. The obtained results confirm H4. Since Extroversion was found to be negatively correlated with COVID-19 
anxiety syndrome [89], it was supposed that Extroversion negatively affects Travel anxiety (H9). The results show that there is no significant influence of Extroversion on Travel anxiety, which rejected H9. The alternative explanation could be reflected in the fact that socializing with others is how extroverts recharge their batteries. Among extroverts, months of quarantine and various protective measures affected the need for socialization, including the need to travel. Insignificant results can be explained through the fact that extroverts rushed to travel after the lifting of the measures, without developing a state of anxiety from traveling. If we consider the abovementioned facts, it was assumed that persons with extroversion traits have higher intentions to travel (H14). The results show significant positive effects of Extroversion on Travel intentions, which is in accordance with previous research [84], and confirms H14.

Agreeableness. In previous studies, a negative association has been found between Agreeableness and social distancing [111], which indicated their characteristics of generosity, helpfulness, and empathy [112]. People who score high in Agreeableness like to volunteer and to make social contacts, which increases their likelihood to be infected. Based on this, it was assumed that people who had agreeableness characteristics will express lower Fear of COVID-19. The results show negative correlation between these two variables and provide support for $\mathrm{H} 5$. In continuation of this, it was expected that those who score high in Agreeableness would express lower Travel anxiety and higher Travel intention. By testing mutual influences, it was obtained that there were no significant effects of Agreeableness on Travel anxiety (H10) and Travel intention (H15). Since no presumed connections were obtained, the authors believe that an alternative explanation could be found in the fact that people with more agreeable personality are more likely to function well in the restricted settings during lockdowns and social distance limitations [113], which may justify the absence of a significant relationship between the variables tested.

Neuroticism. Since Neuroticism is correlated with most of the emotional disorders [114,115], it was expected that people with higher scores of Neuroticism will express higher Fear of COVID-19 (H7), as well as higher Travel anxiety (H12). Our results indicate strong effects of Neuroticism on Fear of COVID-19, which confirms H7. These results confirm the earlier findings obtained in similar studies related to coronavirus epidemics $[35,85,116]$. In addition to this, Neuroticism was positively correlated with Travel anxiety (H12), which confirmed the results from previous studies and provided support for H12. The results show negative correlation between Neuroticism and Travel intention which provided support for H17. Even in the case of different results, it would not be surprising and difficult to explain that when coping with a pandemic disease, persons who are prone to neuroticism may exhibit inconsistency in their behavior, which may be related to their level of neuroticism. Persons who express higher levels of fear and anxiety, for example, prefer to use denial as a psychological defense strategy to alleviate their fears; this implies that they participate in risky activities to feel psychologically safe [117-119]. This practically means that they would dare to travel even though it is risky.

Conscientiousness. Like the people with neuroticism, those who have conscientiousness traits can be related with conforming to social standards and engaging in social distancing [111] and handwashing [120] during the pandemic of COVID-19. Hence it was expected that Conscientiousness has positive correlation with Fear of COVID-19 (H6) and Travel anxiety (H11). The results show that people who score high in Conscientiousness express higher Fear of COVID-19 and Travel anxiety, which confirmed H6 and H11. Higher Conscientiousness is associated with higher likelihood of taking preventing measures $[111,120]$ which might negatively affect Travel intention, which was confirmed in this study (H16). These results are not surprising due to the fact that people who score higher in Conscientiousness look ahead and consider how their actions influence other people. They do not make rash or thoughtless decisions, which is also applicable in the case of behavior and travel decisions during coronavirus.

Openness. In previous studies, the negative relationship between Openness, Agreeableness, Extroversion and anxiety, negative feelings, and depression [121,122] was deter- 
mined. Based on that, it was expected that Openness negatively affects Fear of COVID-19 (H8) and Travel anxiety (H13). The results reject both hypotheses because there is no notable relationship. The possible explanation which the authors could offer is the fact that the coronavirus has been present in people's lives for a long time, and that they have become accustomed to living with it. The assumption is that the initial fear of infection gradually decreased over time, which may vindicate truancy of a significant impact of Agreeableness on Fear of COVID-19 and Travel anxiety. According to Götz et al. [123], people who are open are less conformist and tend to strive for experiences that are unconventional [124], hence it was expected that Openness would positively affects Travel intention (H18). Since analysis showed positive impact of Openness on Travel intention, the H18 is supported.

\section{Conclusions}

One of the most significant and unfortunate occurrences of contemporary times was the outbreak of COVID-19. This led to a serious economic crisis, and tourism and hospitality industry are the most impacted. Pandemic future development is still unknown which makes it difficult to assess the impact on tourism and hospitality. In the conditions of global pandemic, tourism and hospitality are under the influence of the factors which shape users' behavior, such as: perceived health risk, preventive measures prescribed by the government, their income, or the fear of getting infected. The mentioned factors may be perceived in different ways depending on the consumers' personality traits. The results obtained in this research proved that some of the personality traits can have a significant impact not only on travel intentions, but also on the fear of the global pandemic, as well as on the occurrence of travel anxiety. In this study, 18 hypotheses were tested, eleven of which were confirmed. The greatest negative impact on the travel intentions of the respondents from the urban centers of Serbia was the one of the Conscientiousness, while the greatest positive impact was confirmed for Extroversion. In order to preserve the economic stability of tourism and hospitality companies, it is necessary to respect all the suggested measures which will not only reduce the risk of infection transfer, but they will also contribute to the creation of the atmosphere in which tourists feel safe, which will further mitigate their anxiety and fear.

Finally, this study is important because there were no instruments available to measure Fear of COVID-19 in Serbia. Although this scale has been validated in many languages e.g., [46,125-129], this study established Fear of COVID-19 scale (FCV-19S) as a confident and valid tool for evaluating fear associated with COVID-19 on the Serbian sample, which reflects the main contribution of the conducted study.

\section{Limitations and Future Research}

There are several limitations that should be considered. First of all, the questionnaire used in this research was based on self-report measures, which can result in more subjective perception of the measured variables. Secondly, the sampling was carried out based on the principle of a random appropriate sample, so the obtained results cannot be generalized. Moreover, the sample included only the respondents in urban centers, which points to the need to expand the research to the rural areas of Serbia as well. Additionally, the questionnaire should contain additional information about the respondents that relate to their health state and the health state of their family members in order to investigate whether the fear of COVID-19 has a significant connection with vulnerable groups in the population (e.g., patients with chronic diseases, pregnant women, elderly people). In previous studies, the impact of demographic factors was identified. For example, women expressed higher levels of emotional distress and negative thoughts related to COVID-19 compared to men $[122,130,131]$. Additionally, other reports indicated that parents are more likely to become more concerned [132], because they tend to worry not just about the health of their families and their own health, but about the health of their family and children [122,131]. Hence, due to the established importance of sociodemographic factors in coping with the pandemic caused by COVID-19, the recommendation for future research 
is to include these variables in the analyses in order to better understand the reactions to COVID-19. Finally, the further course of pandemic is uncertain. The epidemiological image in the world is changing every day, as well as the preventive measures related to the process of traveling and staying in hospitality facilities. Due to this, it is necessary to perform continuous research of tourists' attitudes so that the sector of tourism and hospitality should have a timely response to the challenges placed by the global pandemic.

Author Contributions: Conceptualization, J.T., I.B. and M.D.P.; methodology, I.B., J.T. and M.D.P.; formal analysis, I.B. and J.T.; investigation, J.T., I.B., M.D.P., S.V., M.B. and V.G.; writing-original draft preparation, J.T., I.B., S.V. and M.B.; writing-review and editing, T.G. and D.L.; visualization, V.G. and T.G. All authors have read and agreed to the published version of the manuscript.

Funding: This research received no external funding.

Institutional Review Board Statement: Institutional Review Board Statement is not required for this paper in Serbia.

Informed Consent Statement: Informed consent was obtained from all subjects involved in the study.

Data Availability Statement: Data available on request due to restrictions.

Conflicts of Interest: The authors declare no conflict of interest.

\section{References}

1. Cao, W.; Fang, Z.; Hou, G.; Han, M.; Xu, X.; Dong, J.; Zheng, J. The psychological impact of the COVID-19 epidemic on college students in China. Psychiatry Res. 2020, 287, 112934. [CrossRef]

2. Erokhin, V.; Gao, T. Impacts of COVID-19 on Trade and Economic Aspects of Food Security: Evidence from 45 Developing Countries. Int. J. Environ. Res. Public Health 2020, 17, 5775. [CrossRef]

3. Mouloudj, K.; Bouarar, A.C.; Fechit, H. The impact of COVID-19 pandemic on food security. Cah. Cread. 2020, 36, 159-184. [CrossRef]

4. Au, A.K.M.; Ramasamy, B.; Yeung, M.C.H. The effects of SARS on the Hong Kong tourism industry: An empirical evaluation. Asia Pac. J. Tour. Res. 2005, 10, 85-95. [CrossRef]

5. Ivanov, S.H.; Webster, C.; Stoilova, E.; Slobodskoy, D. Biosecurity, crisis management, automation technologies and economic performance of travel, tourism and hospitality companies A conceptual framework. Tour. Econ. 2020. [CrossRef]

6. Zhang, K.; Hou, Y.; Li, G. Threat of infectious disease during an outbreak: Influence on tourists' emotional responses to disadvantaged price inequality. Ann. Tour. Res. 2020, 84, 102993. [CrossRef]

7. Gajić, T.; Petrović, M.D.; Radovanović, M.M.; Tretiakova, T.N.; Syromiatnikova, J.A. Possibilities of Turning Passive Rural Areas into Tourist Attractions Through Attained Service Quality. Eur. Ctry. 2020, 12, 179-192. [CrossRef]

8. Yang, Y.; Zhang, H.; Chen, X. Coronavirus pandemic and tourism: Dynamic stochastic general equilibrium modeling of infectious disease outbreak. Ann. Tour. Res. 2020, 83, 102913. [CrossRef]

9. Zhai, X.; Zhong, D.; Luo, Q. Turn it around in crisis communication: An ABM approach. Ann. Tour. Res. 2019, 79. [CrossRef]

10. Williams, C.C.; Kayaoglu, A. COVID-19 and undeclared work: Impacts and policy responses in Europe. Serv. Ind. J. 2020, 40, 914-931. [CrossRef]

11. Fuchs, G.; Reichel, A. Tourist Destination Risk Perception: The Case of Israel. J. Hosp. Leis. Mark. 2006, 14, 83-108. [CrossRef]

12. Xiang, Y.-T.; Yang, Y.; Li, W.; Zhang, L.; Zhang, Q.; Cheung, T.; Ng, C.H. Timely mental health care for the 2019 novel coronavirus outbreak is urgently needed. Lancet Psychiatry 2020, 7, 228-229. [CrossRef]

13. Balaratnasingam, S.; Janca, A. Mass hysteria revisited. Curr. Opin. Psychiatry 2006, 19, 171-174. [CrossRef]

14. Conway III, L.G.; Woodard, S.R.; Zubrod, A. Social psychological measurements of COVID-19: Coronavirus perceived threat, government response, impacts and experiences questionnaires. PsyArXiv 2020. [CrossRef]

15. Spitzmuller, C.; Krishnamoorti, R.; Flin, R.; Datta, A. The Energy Workforce and COVID-19: Data-Driven Policy Recommendations; University of Houston: Houston, TX, USA, 2020.

16. Chang, S. Australians' Holiday Decisions in China: A Study Combining Novelty-Seeking and Risk-Perception Behaviors. J. China Tour. Res. 2009, 5, 364-387. [CrossRef]

17. Taylor, S. The Psychology of Pandemics: Preparing for the Next Global Outbreak of Infectious Disease; Cambridge Scholars Publishing: Newcastle, UK, 2019.

18. Biggs, A.T.; Clark, K.; Mitroff, S.R. Who should be searching? Differences in personality can affect visual search accuracy. Pers. Individ. Differ. 2017, 116, 353-358. [CrossRef]

19. Di Crosta, A.; Palumbo, R.; Marchetti, D.; Ceccato, I.; La Malva, P.; Maiella, R.; Cipi, M.; Roma, P.; Mammarella, N.; Verrocchio, M.C.; et al. Individual Differences, Economic Stability, and Fear of Contagion as Risk Factors for PTSD Symptoms in the COVID-19 Emergency. Front. Psychol. 2020, 11, 567367. [CrossRef] 
20. Bibbey, A.; Carroll, D.; Roseboom, T.J.; Phillips, A.C.; de Rooij, S.R. Personality and physiological reactions to acute psychological stress. Int. J. Psychophysiol. 2012, 90, 28-36. [CrossRef] [PubMed]

21. Oshio, A.; Taku, K.; Hirano, M.; Saeed, G. Resilience and Big Five personality traits: A meta-analysis. Pers. Individ. Differ. 2018, 127, 54-60. [CrossRef]

22. Afshar, H.; Roohafza, H.; Keshteli, A.H.; Mazaheri, M.; Feizi, A.; Adibi, P. The association of personality traits and coping styles according to stress level. J. Res. Med. Sci. 2015, 20, 353-358.

23. Costa, P.T.; McCrae, R.R. Age changes in personality and their origins: Comment on Roberts, Walton, and Viechtbauer (2006). Psychol. Bull. 2006, 132, 26-28. [CrossRef] [PubMed]

24. Reardon, S. Ebola's mental-health wounds linger in Africa. Nature 2015, 519, 13-14. [CrossRef]

25. Steimer, T. The biology of fear- and anxiety-related behaviors. Dialogue Clin. Neurosci. 2002, 4, 231-249. [CrossRef]

26. Holmes, E.A.; O'Connor, R.C.; Perry, V.H.; Tracey, I.; Wessely, S.; Arseneault, L.; Ballard, C.; Christensen, H.; Silver, R.C.; Everall, I.; et al. Multidisciplinary research priorities for the COVID-19 pandemic: A call for action for mental health science. Lancet Psychiatry 2020, 7, 547-560. [CrossRef]

27. Sep, M.S.; Steenmeijer, A.; Kennis, M. The relation between anxious personality traits and fear generalization in healthy subjects: A systematic review and meta-analysis. Neurosci. Biobehav. Rev. 2019, 107, 320-328. [CrossRef]

28. Winter, T.; Riordan, B.C.; Pakpour, A.; Griffiths, M.D.; Mason, A.; Poulgrain, J.W.; Scarf, D. Evaluation of the English Version of the Fear of COVID-19 Scale and Its Relationship with Behavior Change and Political Beliefs. Int. J. Ment. Health Addict. 2020, 1-11. [CrossRef] [PubMed]

29. Harper, C.A.; Satchell, L.P.; Fido, D.; Latzman, R.D. Functional Fear Predicts Public Health Compliance in the COVID-19 Pandemic. Int. J. Ment. Health Addict. 2020, 1-14. [CrossRef] [PubMed]

30. Ahorsu, D.K.; Lin, C.-Y.; Imani, V.; Saffari, M.; Griffiths, M.D.; Pakpour, A.H. The Fear of COVID-19 Scale: Development and Initial Validation. Int. J. Ment. Health Addict. 2020, 1-9. [CrossRef]

31. Choi, E.P.H.; Hui, B.P.H.; Wan, E.Y.F. Depression and Anxiety in Hong Kong during COVID-19. Int. J. Environ. Res. Public Health 2020, 17, 3740. [CrossRef]

32. Arpaci, I.; Karataş, K.; Baloğlu, M. The development and initial tests for the psychometric properties of the COVID-19 Phobia Scale (C19P-S). Pers. Individ. Differ. 2020, 164, 110108. [CrossRef] [PubMed]

33. Qiu, J.; Shen, B.; Zhao, M.; Wang, Z.; Xie, B.; Xu, Y. A nationwide survey of psychological distress among Chinese people in the COVID-19 epidemic: Implications and policy recommendations. Gen. Psychiatry 2020, 33, e100213. [CrossRef]

34. Fernández, R.S.; Crivelli, L.; Guimet, N.M.; Allegri, R.F.; Pedreira, M.E. Psychological distress associated with COVID-19 quarantine: Latent profile analysis, outcome prediction and mediation analysis. J. Affect. Disord. 2020, 277, 75-84. [CrossRef]

35. Nazari, N.; Zekiy, A.O.; Feng, L.-S.; Griffiths, M.D. Psychometric Validation of the Persian Version of the COVID-19-Related Psychological Distress Scale and Association with COVID-19 Fear, COVID-19 Anxiety, Optimism, and Lack of Resilience. Int. J. Ment. Health Addict. 2021, 1-16. [CrossRef]

36. Arkin, R.M.; Ruck, L. Anxiety. In Encyclopedia of Social Psychology; Baumeister, R.F., Vohs, K.D., Eds.; Sage: Thousand Oaks, CA, USA, 2007; pp. 42-43.

37. Blumberg, S.H.; Izard, C.E. Discriminating patterns of emotions in 10- and 11-yr-old children's anxiety and depression. J. Pers. Soc. Psychol. 1986, 51, 852-857. [CrossRef]

38. Chiou, W.-B.; Wan, C.S. The effects of anxiety and sadness on travelers' decisions and perceived risk: Mood management as an active process of affect-adjustment. AP Asia-Pac. Adv. Consum. Res. 2006, 7, 385-392.

39. Reisinger, Y.; Mavondo, F. Travel Anxiety and Intentions to Travel Internationally: Implications of Travel Risk Perception. J. Travel Res. 2005, 43, 212-225. [CrossRef]

40. Asmundson, G.J.; Taylor, S. Coronaphobia: Fear and the 2019-nCoV outbreak. J. Anxiety Disord. 2020, 70, 102196. [CrossRef] [PubMed]

41. Tanner, C. When Coronaphobia Turns into Agoraphobia: 'I Struggle to Even Go Out for a Walk'. I News. 2020. Available online: https://inews.co.uk/news/coronavirus-uk-latest-lockdown-restrictions-coronaphobia-agoraphobia-mental-health-43 4506 (accessed on 27 October 2021).

42. Wu, L.; Zhang, J.; Fujiwara, A. Representing tourists' heterogeneous choices of destination and travel party with an integrated latent class and nested logit model. Tour. Manag. 2011, 32, 1407-1413. [CrossRef]

43. Chandler, J. How Safe Are Our Airports? Travel Leisure 1991, 21, 94-100.

44. Englander, D. What You Need to Know to Fly Safely Now. Money 1991, 29, 156.

45. Luo, J.; Lam, C. Travel Anxiety, Risk Attitude and Travel Intentions towards "Travel Bubble" Destinations in Hong Kong: Effect of the Fear of COVID-19. Int. J. Environ. Res. Public Health 2020, 17, 7859. [CrossRef] [PubMed]

46. Satici, B.; Gocet-Tekin, E.; Deniz, M.E.; Satici, S.A. Adaptation of the Fear of COVID-19 Scale: Its Association with Psychological Distress and Life Satisfaction in Turkey. Int. J. Ment. Health Addict. 2020, 1-9. [CrossRef] [PubMed]

47. Beck, M.J.; Hensher, D.A. Insights into the impact of COVID-19 on household travel and activities in Australia the early days under restrictions. Transp. Policy 2020, 96, 76-93. [CrossRef] [PubMed]

48. Wen, J.; Kozak, M.; Yang, S.; Liu, F. COVID-19: Potential effects on Chinese citizens' lifestyle and travel. Tour. Rev. 2020, 76, 74-87. [CrossRef] 
49. Nicola, M.; Alsafi, Z.; Sohrabi, C.; Kerwan, A.; Al-Jabir, A.; Iosifidis, C.; Agha, M.; Agha, R. The socio-economic implications of the coronavirus and COVID-19 pandemic: A review. Int. J. Surg. 2020, 78, 185-193. [CrossRef] [PubMed]

50. American Hotel \& Lodging Association (AHLA). Leisure and Hospitality Industry Proves Hardest Hit by COVID-19. Available online: https:/ / www.ahla.com/covid-19s-impact-hotel-industry (accessed on 5 September 2021).

51. Kroencke, L.; Geukes, K.; Utesch, T.; Kuper, N.; Back, M. Neuroticism and emotional risk during the COVID-19 pandemic. J. Res. Pers. 2020, 89, 104038. [CrossRef]

52. Zhang, J.; Lu, H.; Zeng, H.; Zhang, S.; Du, Q.; Jiang, T.; Du, B. The differential psychological distress of populations affected by the COVID-19 pandemic. Brain Behav. Immun. 2020, 87, 49-50. [CrossRef]

53. Duan, L.; Zhu, G. Psychological interventions for people affected by the COVID-19 epidemic. Lancet Psychiatry 2020, 7, 300-302. [CrossRef]

54. Gajić, T.; Petrović, M.D.; Blešić, I.; Radovanović, M.M.; Syromiatnikova, J.A. The power of fears in the travel decision-covid-19 against lack of money. J. Tour. Futures 2021, 1-22. [CrossRef]

55. Miller, N.E.; Dollard, J. Social Learning and Imitation; Yale University Press: New Haven, CT, USA, 1941.

56. Scott, S.G.; Bruce, R.A. Decision-Making Style: The Development and Assessment of a New Measure. Educ. Psychol. Meas. 1995, 55, 818-831. [CrossRef]

57. Riaz, M.N.; Riaz, M.A.; Batool, N. Personality Types as Predictors of Decision Making Styles. J. Behav. Sci. 2012, $22,99-114$.

58. Digman, J.M. Five Robust Trait Dimensions: Development, Stability, and Utility. J. Pers. 1989, 57, 195-214. [CrossRef]

59. Digman, J.M.; Inouye, J. Further specification of the five robust factors of personality. J. Pers. Soc. Psychol. 1986, 50, 116-123. [CrossRef]

60. Mervielde, I.; Buyst, V.; De Fruyt, F. The validity of the Big-five as a model for teachers' ratings of individual differences among children aged 4-12 years. Pers. Individ. Differ. 1995, 18, 525-534. [CrossRef]

61. Mirhaghi, M.; Sarabian, S. Relati between perceived stress and personality trait in emergency medical personnel. J. Fundam. Ment. Health 2016, 18, 265-271. [CrossRef]

62. Agbaria, Q.; Abu Mokh, A. Coping with Stress During the Coronavirus Outbreak: The Contribution of Big Five Personality Traits and Social Support. Int. J. Ment. Health Addict. 2021, 1-19. [CrossRef]

63. Costa, P.T.; McCrae, R.R. The Revised NEO Personality Inventory (NEO-PI-R); Sage Publications: Thousand Oaks, CA, USA, 2012; pp. 179-198. [CrossRef]

64. Barlow, D.H.; Sauer-Zavala, S.; Carl, J.R.; Bullis, J.R.; Ellard, K.K. The Nature, Diagnosis, and Treatment of Neuroticism. Clin. Psychol. Sci. 2013, 2, 344-365. [CrossRef]

65. Lahey, B.B. Public health significance of neuroticism. Am. Psychol. 2009, 64, 241-256. [CrossRef] [PubMed]

66. Lucas, R.E. Exploring the associations between personality and subjective well-being. In Handbook of Well-Being; Diener, E., Oishi, S., Tay, L., Eds.; DEF Publishers: Salt Lake City, UT, USA, 2018; pp. 257-271.

67. Soto, C.J. How Replicable Are Links Between Personality Traits and Consequential Life Outcomes? The Life Outcomes of Personality Replication Project. Psychol. Sci. 2019, 30, 711-727. [CrossRef] [PubMed]

68. Kotov, R.; Gamez, W.; Schmidt, F.; Watson, D. Linking “big" personality traits to anxiety, depressive, and substance use disorders: A meta-analysis. Psychol. Bull. 2010, 136, 768-821. [CrossRef]

69. Malouff, J.M.; Thorsteinsson, E.B.; Schutte, N.S. The Relationship Between the Five-Factor Model of Personality and Symptoms of Clinical Disorders: A Meta-Analysis. J. Psychopathol. Behav. Assess. 2005, 27, 101-114. [CrossRef]

70. McCrae, R.R.; John, O.P. An Introduction to the Five-Factor Model and Its Applications. J. Pers. 1992, 60, 175-215. [CrossRef] [PubMed]

71. McCrae, R.R.; Costa, P.T. Validation of the five-factor model of personality across instruments and observers. J. Pers. Soc. Psychol. 1987, 52, 81-90. [CrossRef]

72. Hisler, G.C.; Krizan, Z.; DeHart, T.; Wright, A.G. Neuroticism as the intensity, reactivity, and variability in day-to-day affect. J. Res. Pers. 2020, 87, 103964. [CrossRef]

73. Iterbeke, K.; De Witte, K. Helpful or harmful? The role of personality traits in student experiences of the COVID-19 crisis and school closure. FEB Res. Rep. Dep. Econ. 2020. [CrossRef]

74. Mohamed, Z. Adult Personality and its Relationship with Stress Level and Coping Mechanism among Final Year Medical Students. Med. Health 2019, 14, 154-167. [CrossRef]

75. Rammsayer, T.; Weber, H. Differentielle Psychologie-Persönlichkeitstheorien (2. Auflage). Bachelor Thesis, Hogrefe Verlag Göttingen, Göttingen, Germany, 2016.

76. Ozer, D.J.; Benet-Martínez, V. Personality and the Prediction of Consequential Outcomes. Annu. Rev. Psychol. 2006, 57, 401-421. [CrossRef]

77. McCullough, M.E.; Emmons, R.A.; Tsang, J.-A. The grateful disposition: A conceptual and empirical topography. J. Pers. Soc. Psychol. 2002, 82, 112-127. [CrossRef]

78. Thompson, L.Y.; Snyder, C.R.; Hoffman, L.; Michael, S.T.; Rasmussen, H.N.; Billings, L.S.; Heinze, L.; Neufeld, J.E.; Shorey, H.S.; Roberts, J.C.; et al. Dispositional Forgiveness of Self, Others, and Situations. J. Pers. 2005, 73, 313-360. [CrossRef]

79. Boone, C.; De Brabander, B.; van Witteloostuijn, A. The impact of personality on behavior in five Prisoner's Dilemma games. J. Econ. Psychol. 1999, 20, 343-377. [CrossRef]

80. Tyler, T.R.; Blader, S.L. Identity and Cooperative Behavior in Groups. Group Process. Intergroup Relat. 2001, 4, 207-226. [CrossRef] 
81. Van Dijk, S.; Hanssen, D.; Naarding, P.; Lucassen, P.; Comijs, H.; Voshaar, R.O. Big Five personality traits and medically unexplained symptoms in later life. Eur. Psychiatry 2016, 38, 23-30. [CrossRef]

82. Mortensen, C.R.; Becker, D.V.; Ackerman, J.M.; Neuberg, S.L.; Kenrick, D.T. Infection Breeds Reticence. Psychol. Sci. 2010, 21, 440-447. [CrossRef] [PubMed]

83. Bogg, T.; Roberts, B.W. Conscientiousness and Health-Related Behaviors: A Meta-Analysis of the Leading Behavioral Contributors to Mortality. Psychol. Bull. 2004, 130, 887-919. [CrossRef]

84. Maritz, A.; Yeh, S.; Shieh, C. Effects of personality trait on perceived risk and travel intention in tourism industry. Actual Probl. Econ. 2013, 2, 103-109.

85. Aschwanden, D.; Strickhouser, J.E.; Sesker, A.; Lee, J.H.; Luchetti, M.; Stephan, Y.; Sutin, A.R.; Terracciano, A. Psychological and behavioural responses to Coronavirus disease 2019: The role of personality. Eur. J. Pers. 2020, 35, 51-66. [CrossRef]

86. Liu, S.; Lithopoulos, A.; Zhang, C.-Q.; Garcia-Barrera, M.A.; Rhodes, R.E. Personality and perceived stress during COVID-19 pandemic: Testing the mediating role of perceived threat and efficacy. Pers. Individ. Differ. 2020, 168, 110351. [CrossRef] [PubMed]

87. Garbe, L.; Rau, R.; Toppe, T. Influence of perceived threat of Covid-19 and HEXACO personality traits on toilet paper stockpiling. PLoS ONE 2020, 15, e0234232. [CrossRef] [PubMed]

88. Zettler, I.; Schild, C.; Lilleholt, L.; Kroencke, L.; Utesch, T.; Moshagen, M.; Böhm, R.; Back, M.D.; Geukes, K. The Role of Personality in COVID-19-Related Perceptions, Evaluations, and Behaviors: Findings Across Five Samples, Nine Traits, and 17 Criteria. Soc. Psychol. Pers. Sci. 2021. [CrossRef]

89. Nikčević, A.V.; Marino, C.; Kolubinski, D.C.; Leach, D.; Spada, M.M. Modelling the contribution of the Big Five personality traits, health anxiety, and COVID-19 psychological distress to generalised anxiety and depressive symptoms during the COVID-19 pandemic. J. Affect. Disord. 2020, 279, 578-584. [CrossRef]

90. Qian, K.; Yahara, T. Mentality and behavior in COVID-19 emergency status in Japan: Influence of personality, morality and ideology. PLoS ONE 2020, 15, e0235883. [CrossRef]

91. Blagov, P.S. Adaptive and Dark Personality in the COVID-19 Pandemic: Predicting Health-Behavior Endorsement and the Appeal of Public-Health Messages. Soc. Psychol. Pers. Sci. 2020, 12, 697-707. [CrossRef]

92. Bayanfar, F. Predicting corona disease anxiety among medical staffs in Tehran based on Five Factor theory of personality. Iran. J. Health Psychol. 2020, 2, 113-126. [CrossRef]

93. Watson, D.; Clark, L.A. Personality traits as an organizing framework for personality pathology. Pers. Ment. Health 2019, 14, 51-75. [CrossRef]

94. Wachyuni, S.S.; Kusumaningrum, D.A. The Effect of COVID-19 Pandemic: How are the Future Tourist Behavior? J. Educ. Soc. Behav. Sci. 2020, 67-76. [CrossRef]

95. Costa, P.; McCrae, R.R. Four ways five factors are basic. Pers. Individ. Differ. 1992, 13, 653-665. [CrossRef]

96. McCrae, R.R.; Costa, J.C.P. Personality trait structure as a human universal. Am. Psychol. 1997, 52, 509-516. [CrossRef]

97. Nicholson, N.; Soane, E.; Fenton-O'Creevy, M.; Willman, P. Personality and domain-specific risk taking. J. Risk Res. 2005, 8, 157-176. [CrossRef]

98. John, O.P.; Srivastava, S. The Big-Five trait taxonomy: History, measurement, and theoretical perspectives. In Handbook of Personality: Theory and Research; Pervin, L.A., John, O.P., Eds.; Guilford Press: New York, NY, USA, 1999; Volume 2, pp. 102-138.

99. Obradovic, D. Model regionalizacije centralne Srbije. J. Geogr. Inst. Jovan Cvijic SASA 2007, 309-317. [CrossRef]

100. Fornell, C.; Larcker, D.F. Evaluating Structural Equation Models with Unobservable Variables and Measurement Error. J. Mark. Res. 1981, 18, 39-50. [CrossRef]

101. Kline, R.B. Principles and Practice of Structural Equation Modeling, 3rd ed.; The Guilford Press: New York, NY, USA, 2011.

102. Hair, J.F., Jr.; Hult, G.T.M.; Ringle, C.; Sarstedt, M. A Primer on Partial Least Squares Structural Equation Modeling (PLS-SEM); Sage Publications: Los Angeles, CA, USA, 2017.

103. Nunnally, J.C. Psychometric Theory; McGraw-Hill: New York, NY, USA, 1978.

104. Barlow, D.H. Unraveling the mysteries of anxiety and its disorders from the perspective of emotion theory. Am. Psychol. 2000, 55, 1247-1263. [CrossRef]

105. Karagöz, D.; Işık, C.; Dogru, T.; Zhang, L. Solo female travel risks, anxiety and travel intentions: Examining the moderating role of online psychological-social support. Curr. Issues Tour. 2020, 24, 1595-1612. [CrossRef]

106. Commissioner for Information of Public Importance and Personal Data Protection. Available online: https://www.poverenik.rs / sr-yu/covid-19 (accessed on 25 October 2021).

107. Statistical Annual Register of the Republic of Serbia. 2020. Available online: https://www.stat.gov.rs/sr-cyrl/publikacije/ publication/?p=12694 (accessed on 25 October 2021).

108. Statistical Annual Register of the Republic of Serbia. 2021. Available online: https://www.stat.gov.rs/sr-cyrl/publikacije/ publication/?p=13253 (accessed on 25 October 2021).

109. Abdullah, M.N. Revenge tourism: Trend or impact post-pandemic Covid-19? In Promoting Creative Tourism: Current Issues in Tourism Research; eBook; Routledge: Oxford, UK, 2021; pp. 623-627. ISBN 9781003095484.

110. Nazari, N.; Griffiths, M.D. Psychometric validation of the Persian version of the Emotional Style Questionnaire. Curr. Psychol. 2020, 1-13. [CrossRef]

111. Abdelrahman, M. Personality Traits, Risk Perception, and Protective Behaviors of Arab Residents of Qatar During the COVID-19 Pandemic. Int. J. Ment. Health Addict. 2020, 1-12. [CrossRef] [PubMed] 
112. Graziano, W.G.; Habashi, M.M.; Sheese, B.E.; Tobin, R.M. Agreeableness, empathy, and helping: A person $\times$ situation perspective. J. Pers. Soc. Psychol. 2007, 93, 583-599. [CrossRef]

113. Deyoung, C.G.; Gray, J.R. Personality neuroscience: Explaining individual differences in affect, behaviour and cognition. In The Cambridge Handbook of Personality Psychology; Corr, P.J., Matthews, G., Eds.; Cambridge University Press: Cambridge, UK, 2009; pp. 323-346. [CrossRef]

114. Brown, T.A.; Barlow, D.H. A proposal for a dimensional classification system based on the shared features of the DSM-IV anxiety and mood disorders: Implications for assessment and treatment. Psychol. Assess. 2009, 21, 256-271. [CrossRef] [PubMed]

115. Norton, P.J.; Paulus, D. Transdiagnostic models of anxiety disorder: Theoretical and empirical underpinnings. Clin. Psychol. Rev. 2017, 56, 122-137. [CrossRef]

116. Caci, B.; Miceli, S.; Scrima, F.; Cardaci, M. Neuroticism and Fear of COVID-19. The Interplay Between Boredom, Fantasy Engagement, and Perceived Control Over Time. Front. Psychol. 2020, 11, 574393. [CrossRef] [PubMed]

117. Aronson, E. Fear, denial, and sensible action in the face of disasters. Soc. Res. 2008, 75, 855-872. Available online: www.jstor.org/ stable/40972094 (accessed on 25 October 2021).

118. Florian, V.; Mikulincer, M. Fear of death and the judgment of social transgressions: A multidimensional test of terror management theory. J. Pers. Soc. Psychol. 1997, 73, 369-380. [CrossRef]

119. Peek, M.E.; Sayad, J.V.; Markwardt, R. Fear, Fatalism and Breast Cancer Screening in Low-Income African-American Women: The Role of Clinicians and the Health Care System. J. Gen. Intern. Med. 2008, 23, 1847-1853. [CrossRef] [PubMed]

120. Carvalho, L.D.F.; Pianowski, G.; Gonçalves, A.P. Personality differences and COVID-19: Are extroversion and conscientiousness personality traits associated with engagement with containment measures? Trends Psychiatry Psychother. 2020, 42, 179-184. [CrossRef] [PubMed]

121. Bunevicius, A.; Katkute, A.; Bunevicius, R. Symptoms of Anxiety and Depression in Medical Students and in Humanities Students: Relationship with Big-Five Personality Dimensions and Vulnerability to Stress. Int. J. Soc. Psychiatry 2008, 54, 494-501. [CrossRef] [PubMed]

122. Wang, C.J.; Ng, C.; Brook, R.H. Response to COVID-19 in Taiwan. JAMA 2020, 323, 1341. [CrossRef] [PubMed]

123. Götz, F.M.; Gvirtz, A.; Galinsky, A.D.; Jachimowicz, J.M. How personality and policy predict pandemic behavior: Understanding sheltering-in-place in 55 countries at the onset of COVID-19. Am. Psychol. 2021, 76, 39-49. [CrossRef] [PubMed]

124. Schneider, P.P.; Vogt, C.A. Applying the 3M Model of Personality and Motivation to Adventure Travelers. J. Travel Res. 2012, 51, 704-716. [CrossRef]

125. Sakib, N.; Bhuiyan, A.K.M.I.; Hossain, S.; Al Mamun, F.; Hosen, I.; Abdullah, A.H.; Sarker, A.; Mohiuddin, M.S.; Rayhan, I.; Hossain, M.; et al. Psychometric Validation of the Bangla Fear of COVID-19 Scale: Confirmatory Factor Analysis and Rasch Analysis. Int. J. Ment. Health Addict. 2020, 1-12. [CrossRef] [PubMed]

126. Nikopoulou, V.A.; Holeva, V.; Parlapani, E.; Karamouzi, P.; Voitsidis, P.; Porfyri, G.-N.; Blekas, A.; Papigkioti, K.; Patsiala, S.; Diakogiannis, I. Mental Health Screening for COVID-19: A Proposed Cutoff Score for the Greek Version of the Fear of COVID-19 Scale (FCV-19S). Int. J. Ment. Health Addict. 2020, 1-14. [CrossRef]

127. Alyami, M.; Henning, M.; Krägeloh, C.U.; Alyami, H. Psychometric Evaluation of the Arabic Version of the Fear of COVID-19 Scale. Int. J. Ment. Health Addict. 2020, 1-14. [CrossRef]

128. Wakashima, K.; Asai, K.; Kobayashi, D.; Koiwa, K.; Kamoshida, S.; Sakuraba, M. The Japanese version of the Fear of COVID-19 scale: Reliability, validity, and relation to coping behavior. PLoS ONE 2020, 15, e0241958. [CrossRef] [PubMed]

129. Chi, X.; Chen, S.; Chen, Y.; Chen, D.; Yu, Q.; Guo, T.; Cao, Q.; Zheng, X.; Huang, S.; Hossain, M.; et al. Psychometric Evaluation of the Fear of COVID-19 Scale Among Chinese Population. Int. J. Ment. Health Addict. 2021, 1-16. [CrossRef]

130. Liu, N.; Zhang, F.; Wei, C.; Jia, Y.; Shang, Z.; Sun, L.; Wu, L.; Sun, Z.; Zhou, Y.; Wang, Y.; et al. Prevalence and predictors of PTSS during COVID-19 outbreak in China hardest-hit areas: Gender differences matter. Psychiatry Res. 2020, 287, 112921. [CrossRef] [PubMed]

131. Park, C.L.; Russell, B.S.; Fendrich, M.; Finkelstein-Fox, L.; Hutchison, M.; Becker, J. Americans' COVID-19 Stress, Coping, and Adherence to CDC Guidelines. J. Gen. Intern. Med. 2020, 35, 2296-2303. [CrossRef] [PubMed]

132. Liu, C.H.; Doan, S.N. Psychosocial Stress Contagion in Children and Families During the COVID-19 Pandemic. Clin. Pediatr. 2020, 59, 853-855. [CrossRef] [PubMed] 